\title{
The international regime for investment: A history of failed multilateralism
}

\author{
Tarald Laudal Berge* and Helge Hveem ${ }^{* *}$
}

May 2, 2019

\section{Introduction}

In the post-war era, international economic relations have in most areas come to be governed multilaterally. International trade is governed through the General Agreement on Trade and Tariffs (GATT) and later the World Trade Organization (WTO), while the International Monetary Fund (IMF) govern international monetary relations. But all attempts to establish a worldwide multilateral investment regime have failed. That is peculiar, given the parallel liberalization of trade and investment and the inter-dependencies between these issue-areas, but the absence of an accord has not been for the lack of attempts. Discussions around governance codes have for decades taken place within the WTO, under the Organization for Economic Development and Cooperation (OECD), and in the United Nations (UN) system.

What has instead come to be the modus operandi of the investment regime are rules enshrined in a wide network of bilateral investment treaties (BITs), with dispute settlement through investment treaty arbitration (ITA). And for years, states have seemed quite content with this regime. But in the last decade, its legitimacy has come under attack. In parallel with halting ongoing plurilateral or mega-regional trade agreement negotiations with investment, the legitimacy crisis has led to a variety of reform proposals. In this chapter, we address two interrelated questions pertaining to these old and new debates around investment governance:

(I) Why is there no multilateral agreement for protecting investment?

\footnotetext{
* Doctoral Candidate, Department of Political Science and PluriCourts Centre of Excellence, University of Oslo. Email: t.1.berge@stv.uio.no

** Professor Emeritus, Department of Political Science and PluriCourts Centre of Excellence, University of Oslo. E-mail: helge.hveem@stv.uio.no
} 
The chapter is structured as follows. First, it offers a thorough historical account of how investment governance and international investment law have developed. Second, we elaborate on the regime based on BITs and ITA that evolved instead. Third, we discuss various explanations for why attempts to broker a multilateral investment agreement have failed, and whether the bilateral investment regime may actually represent a different kind of non-treaty based multilateralism. Fourth, we discuss recent criticism of the bilateral regime's legitimacy, and current developments towards regionalizing the investment regime. The question is whether proposals such as the Trans-Pacific Partnership (TPP) and the TransAtlantic Trade and Investment Partnership (TTIP) may lay the foundation for a set of rules that could be globally applied, and whether regionalism is in fact a more expedient alternative to govern international investment than formalized multilateralism (Hveem, 2006).

\section{A history of failed multilateralism}

Since the early days of international shipping and trade, states have exhibited interest in institutionalising the protection of their nationals' property rights abroad. Two prominent examples are The Treaty of Peace and Friendship between Great Britain and Spain (1667), and The Treaty of Amity, Commerce and Navigation between Great Britain and the US (1794) (Brown, 2013, p. 3). Early systems of trade and investment law also developed in Asia, the Middle East and Africa (Sornarajah, 2010, p. 19).

In some relations, states' backed up their interests with gunboat diplomacy, in some colonial conquest and rule, and in others through "normal" diplomacy. But, by the early $19^{\text {th }}$ century, three specific events accelerated states' interest in international codes for investor protection, and with them transformed the international political economy profoundly (Vandevelde, 2010, pp. 20-21). First, the Vienna Congress of 1815 initiated a century of relative peace and prosperity in Europe that would last until the onset of World War I in 1914. This period allowed outwards-looking investors a stable environment to establish their foreign commercial activities. Second, the dawn of the industrial revolution generated large surpluses of goods for export as well as a demand for imported raw materials. These developments in turn drove an uptick in the construction of railroads and increased use of steamboats to reduce transportation costs. The third event was the emergence of liberal economic ideas challenging the current dominant economic doctrine mercantilism - most famously represented by the 
works of Adam Smith and David Ricardo. These events were key drivers of an early process of globalization that substantially increased foreign investment, much of which was funnelled into infrastructure building in the Americas.

Most of these early cross-border investments took the form of bonds (i.e. portfolio investments) as investors found it difficult to conduct what we today would define as foreign direct investments (FDI). In essence, it was difficult to establish substantial ownership of business operations abroad, which is they key to FDI. ${ }^{1}$ Two developments in particular changed this (Vandevelde, 2010, p. 26). The first was the rise of the telegraph, linking countries across the Atlantic closer together, and the second was the development of so-called general incorporation laws in Western Europe and the United States (US) that allowed investors to pool capital in corporations with any given legitimate purpose. Incorporation as such had previously necessitated special legislative approval, leaving investors in a situation where they had to collaborate with domestic businesses. Such collaborative partnerships were very risky, as they made both investors liable for all debts of the joint enterprise.

The sum of these events was that FDI started to flow more freely, but because direct investments are so tightly integrated in host countries the investors were now more concerned with their relation to host governments than the portfolio investors had been. The rule-set in place to govern international investment at the time was customary international law (CIL). ${ }^{2}$ Although multilateral, CIL was limited in scope and application. It contained rules on the protection of foreign investors as part of the broader law of state responsibility, but there was debate between developed and developing countries on how to interpret this standard. Interestingly however, FDI protection was not a concern for the most industrialized nations to begin with. $18^{\text {th }}$ and $19^{\text {th }}$ century investment from these states went almost exclusively to the colonies. These investments were either protected by military force or the export of the colonizer's legal system (Hopkins, 1980; Sornarajah, 2010)

Discussions on an international code for foreign investment therefore arose outside the colonial matrix, spurred by conflicts between the US and Latin American states. The debate was centred on how state responsibility was interpreted under CIL was polarized. The view

\footnotetext{
${ }^{1}$ For an explanation of what constitutes direct investments, and how FDI is measured, see OECD (2008).

${ }^{2}$ Customary international law entails the aspects of international law that pertain to the principle of custom. International courts consider such custom to be the main sources of international law, along with general principles of law and international treaties.
} 
held by most Latin American states was that hosts should give equal treatment to national and foreign investors (i.e. national treatment), and that exclusive jurisdiction over disputes should lie in domestic courts. ${ }^{3}$ However, the US found the domestic standard of protection provided to investors in certain countries to be so low that they demanded foreign investors to be treated by some higher external standard. ${ }^{4}$

It was disagreements like these that eventually led states to pursue a treaty-based system of investor protection. And once decolonization commenced, the need for an international system became apparent to the erstwhile colonial powers as well. Many diplomatic attempts at multilateralism in investment have since been made, but for a variety of reasons they have all failed. Below we discuss some of the major attempts in the post-war era, but as Table 1 illustrates a host of different initiatives were attempted throughout this period. ${ }^{5}$ Some were intergovernmental instruments; some were UN General Assembly Resolutions; some nongovernmental drafts; and some more specific procedural instruments.

Table 1 - Proposed Multilateral Instruments on Protection of Foreign Investment

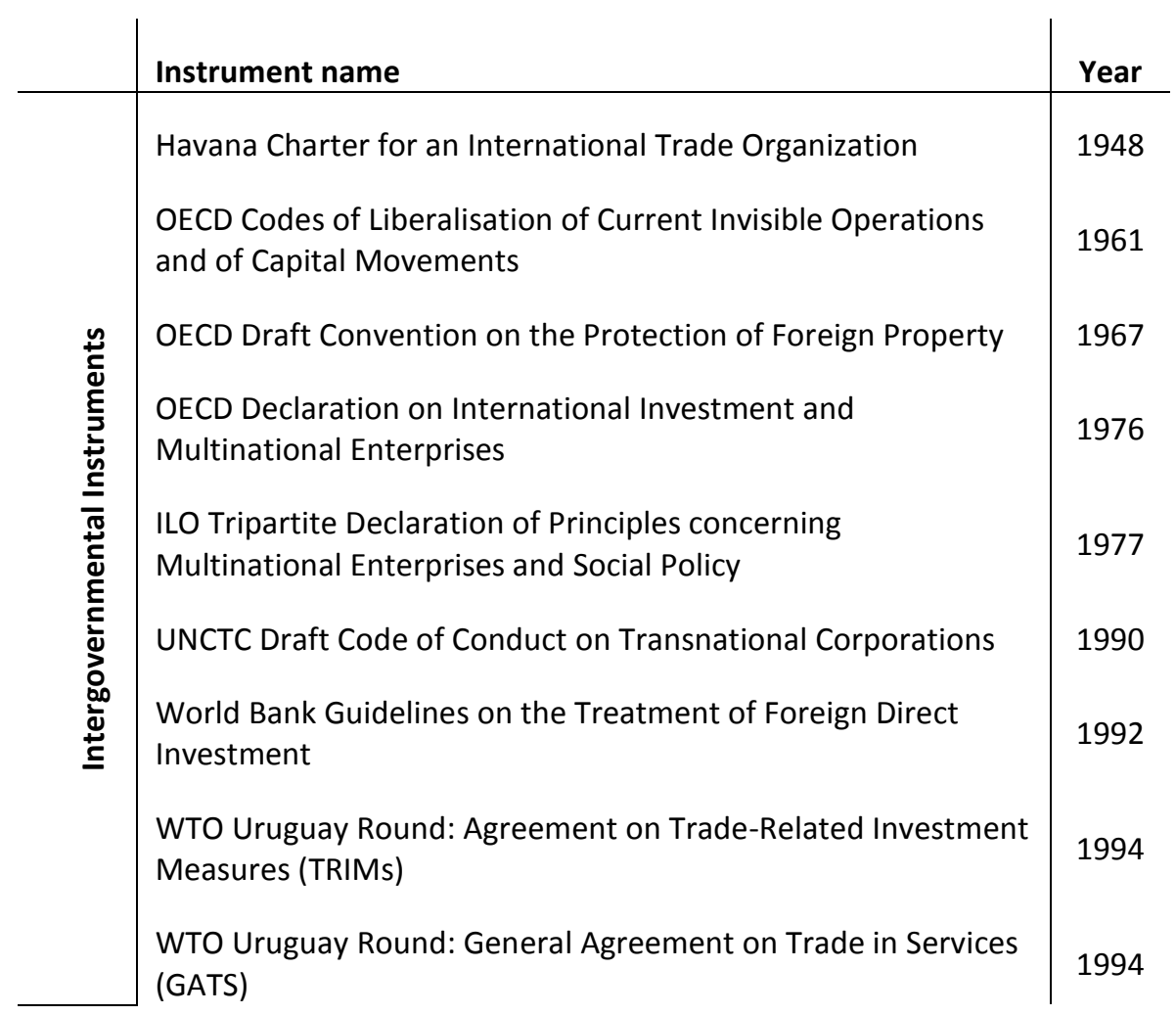

\footnotetext{
${ }^{3}$ This view is often associated with the Calvo Doctrine, named after the Argentine lawyer Carlos Calvo (Shea, 1955).

${ }^{4}$ This view is often associated with the Hull Rule, named after former American Secretary of State, Cordell Hull, who in the wake of a diplomatic dispute between the US and Mexico over a wave of Mexican expropriations put forth the leading formulation on a full compensation standard (Guzman, 1998).

${ }^{5}$ Adapted and expanded from Tschofen (1992, p. 384) by St John (2016, p. 11).
} 


\begin{tabular}{|c|c|c|}
\hline & $\begin{array}{l}\text { OECD Multilateral Agreement on Investment (MAI) } \\
\text { WTO Doha Round: The Working Group on Trade and } \\
\text { Investment }\end{array}$ & 1998 \\
\hline 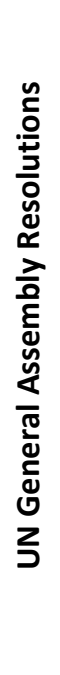 & $\begin{array}{l}\text { UNGA Resolution } 626 \text { (VII) on the Right to Exploit Freely } \\
\text { Natural Wealth and Resources } \\
\text { UNGA Resolution } 1803 \text { (XVII) on Permanent Sovereignty over } \\
\text { National Resources } \\
\text { UNGA Resolution } 2158 \text { (XXI) on Permanent Sovereignty over } \\
\text { Natural Resources } \\
\text { UNGA Resolution } 3171 \text { (XXVIII) on Permanent Sovereignty over } \\
\text { Natural Resources } \\
\text { UNGA Resolution } 3201 \text { (S-VI) Declaration on the Establishment } \\
\text { of a New International Order } \\
\text { UNGA Resolution } 3281 \text { (XXIX) Charter of Economic Rights and } \\
\text { Duties of States }\end{array}$ & $\begin{array}{l}1966 \\
1973 \\
1974\end{array}$ \\
\hline 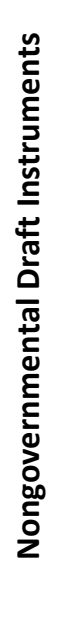 & $\begin{array}{l}\text { ILC Draft Statutes of the Arbitral Tribunal for Foreign } \\
\text { Investment and the Foreign Investment Court } \\
\text { ICC International Code of Fair Treatment for Foreign } \\
\text { Investments } \\
\text { International Convention for the Mutual Protection of Private } \\
\text { Property Rights in Foreign Countries (Abs Draft) } \\
\text { Abs/Shawcross Draft Convention on Investments Abroad } \\
\text { (Abs/Shawcross Draft) } \\
\text { Draft Convention on the International Responsibility of States } \\
\text { for Injuries to Aliens (Harvard Draft) } \\
\text { ICC Guidelines for International Investments }\end{array}$ & $\begin{array}{l}1957 \\
1959 \\
1961 \\
1972\end{array}$ \\
\hline 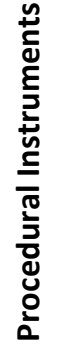 & $\begin{array}{l}\text { Convention on the Recognition and Enforcement of Foreign } \\
\text { Arbitral Awards (New York Convention) } \\
\text { Convention on the Settlement of Investment Disputes between } \\
\text { States and Nations of Other States (ICSID Convention) } \\
\text { United Nations Commission on International Trade Law } \\
\text { (UNCITRAL) Arbitration Rules }\end{array}$ & 1966 \\
\hline
\end{tabular}

Immediately after World War II, negotiators from the United States, Western Europe, Australia and Japan gathered at Bretton Woods to negotiate a new global monetary order. The perception was that the global economy, after two devastating World Wars, was ripe for a multilateral solution to protectionism and speculative capital flows. In this context, an International Trade Organization (ITO) was discussed alongside the IMF and the Bank for Reconstruction and Development (later the World Bank). The ITO negotiations took place in 
Havana, Cuba from 1947 to 1948, under the auspices of the UN. The ITO was meant to cover both international trade and investment, and was envisaged as the third pillar of the Bretton Woods system. However, the final text, the Havana Charter, contained no substantive obligations and only incipient rules on foreign investment protection.

There are two narratives that may help explain the failure of reaching a binding agreement with substantive obligations under ITO (Schill, 2009, pp. 33-35). First, the most prominent capital-exporting party in the negotiations, the US, wished to liberalize the regulation of foreign investment at the same time as providing more effective property rights protection for its investment-oriented industry. However, the developing countries who as a group stood stronger and stronger as the colonial independence movement spread, demanded protection for capital-importing countries rather than capital-exporters. They also wished to maintain more room for domestic regulation than the US negotiators were proposing (Spero \& Hart, 2003, p. 156).

The second explanation is found in US domestic politics and in the emergence of the Cold War. The Republicans, who at the time controlled Congress, were critical of how President Truman of the Democrats had lost China to the Communists. In addition, many members of the business sector were unhappy with the Havana Charter, mostly because of its ambiguous and unbinding language. The US therefore prioritized its international trade interests over investment. President Truman, who faced stark opposition in Congress, focused on getting the Congress to renew the Trade Agreements Act to enable the US to continue negotiating the GATT at the expense of the ITO (Shenkin, 1993). This lack of support from the US in turn led other capital-exporting countries to withdraw support for the ITO, rendering it a fallacy in the end.

The ITO failure foreshadowed the waves of expropriation that would be felt by foreign investors in the 1960s and 1970s. Some instances of takings resulted from shifts in politicaleconomic ideology (like those in Chile from 1973 on and Ethiopia in 1975); some were postindependence takings (Angola and Mozambique in 1975-76) or combinations of the two (Algeria in 1967-72 and Tanzania 1972) (Kobrin, 1980, p. 75). ${ }^{6}$ The unrest among business

\footnotetext{
6 The expropriations were motivated in different ways. On the one side, communist governments held that reconstructing ownership structures along the lines of communist ideology was a different undertaking than takings of property under liberal economic rules. Newly independent countries attempted to extend political independence to economic independence by way of import-substitution strategies. But their economies often remained heavily interlinked with that of their former colonial master. As a result, foreign investment came to be viewed as a form
} 
caused by these expropriations ensured that capital-exporting countries remained focused on establishing a multilateral code on investment. Most attempts were private sector nongovernmental draft instruments (see Table 1), the most prominent being the 1959 AbsShawcross Draft Convention on Investments Abroad. The draft outlined comprehensive protection of foreign investment and introduced substantive and procedural protection provisions that later have become the backbone of BITs. However, the political costs of becoming party to the Convention were viewed as so severe that even moderate capitalimporting countries found it impossible to support it (Schwarzenberger, 1969).

It was therefore never implemented, but the text was taken off the shelf and re-used in its entirety during the next major attempt at a multilateral code on investment: the 1967 OECD Draft Convention on the Protection of Foreign Property. Although negotiations took place under the aegis of the OECD, the Draft Convention was planned as an initiative to be open for later signature by non-OECD members. But, however broad the initiative was, it failed to garner a minimum level of backing from the OECD member countries. It was never even opened for signature. There were two main reasons for why the Draft Convention failed. First, the relative capital-importers within the OECD (Spain, Greece and Portugal) opposed the Draft Convention due to its perceived pro-investor profile. Secondly, the US did not support the effort because they found the expansion of the treaty outside the OECD to be unlikely, and because they saw the need to protect investors within the OECD as marginal.

Although failed, the OECD's work on the Draft Convention was not completely futile. We for example find traces of substantive clauses from the Draft text in early BITs signed by OECD countries. As such it had considerable influence on the bilateral treaty regime that started developing in the 1970's and 1980's. This retreat to bilateralism actually predates the failure of the OECD Draft Convention; the first BIT was concluded between Germany and Pakistan in 1959. However, while multiple other OECD countries were also negotiating BITs in parallel with the OECD Draft Convention, it did not mean they wished to depart from multilateralism in investment governance. Instead it was a reflection of grave concerns over the risk of expropriation their nationals ran when investing abroad.

of neo-colonialism, where the face and power of their former colonizer was projected onto the foreign investors. The result was often policies restricting inward foreign investment, as well as expropriations in key sectors such as infrastructure (Vandevelde, 2010, pp. 41-42). 
As states retreated to bilateralism in investment governance, almost 30 years lapsed before a multilateral code on investment was back on the map. In the meantime, a number of partial attempts at multilateralism were put forth. Some of these were draft codes of conduct for investors attempting to institute a sort of "benevolent unilateralism." The boldest attempt was perhaps the UN Draft Code of Conduct on Transnational Corporations (1978). Its purpose was to stimulate corporate contributions to development in the Global South - in other words a predecessor to the rush of social corporate responsibility codes that started to appear in the 1990s. It was left un-adopted and was finally abandoned in 1992 (Kolk \& Van Tulder, 2005).

In hindsight however, the perhaps most significant initiative in these down years was the conclusion of The Convention on the Settlement of Investment Disputes between States and Nationals of Other States (the ICSID Convention) in the mid 1960's. The Convention established procedural rules for investor-state arbitration in the case of investment disputes, and on the base of it the International Centre for the Settlement of Investment Disputes (ICSID) was set up as an organization under the World Bank Group. ${ }^{7}$ Today, ICSID is by far the most used venue for solving investment disputes under BITs and other investment agreements.

One account of why the ICSID Convention gained so much support is that, unlike previous attempts at multilateralism, it contained no substantive investment rules. Instead, it offered voluntary recourse to investment arbitration for parties to the Convention, and decisions over what constituted applicable law in each disputes was left to the arbitrating parties. As such, it bridged the North-South divide. For capital-exporting states the Convention was seen as a way of depoliticizing conflicts their foreign investors encountered abroad. For capitalimporters, at the time vary of substantive investment protection standards, the Convention had an air of neutrality.

But, as the Cold War was coming to a close, capital-exporting countries again intensified the push for treaty-based multilateralism in investment protection. In the lead up to a GATT ministerial meeting in 1986, the US proposed a comprehensive agreement on investment. But again disagreements were loud. Led by India, the developing countries blocked the initiative. However, during the Uruguay Round of GATT negotiations two agreements with partial

\footnotetext{
${ }^{7}$ For an extensive commentary on the ICSID Convention, see Schreuer (2009).
} 
investment profiles were finally concluded: the agreement on Trade-Related Investment Measures (TRIMs), and the General Agreement on Trade in Services (GATS).

The TRIMs agreement was essentially a compromise between the US (looking for strong investment protection) and the bloc of developing countries (concerned about their room to regulate). The nature of the compromise was a scope of application restricted to investment measures that pertained to trade in goods; it therefore has a very limited role as a multilateral tool for investment protection (Dattu, 2000). The GATS made some headway towards a multilateral scheme for investment protection, and to date contains the single largest set of investment-related provisions negotiated under the GATT/WTO framework (Burt, 1997). GATS regulate trade in services made through the establishment of local service-providing subsidiaries in foreign countries, providing national treatment and most-favoured nation treatment. What distinguished GATS from other parts of the WTO is that it is an opt-in agreement. The fact that WTO members can control their exposure to it is likely one key to its success. And its ability to bridge the North-South ideological divide is in part because it does not concern trade in goods, and in part because it was crafted with a clear development perspective (Kurtz, 2002).

Although the two agreements were encouraging signs for supporters of a multilateral code on investment, the patchwork of protection they offered did in no way mask the fact that capitalimporting countries once more blocked the conclusion of a framework of substantive rules for the protection of all foreign investment. But the dialogue continued within the newly formed WTO and was to re-surface in the early 2000's. In the meantime, there was a forum shift as a new attempt at reaching an investment agreement started in the OECD.

Negotiations for the Multilateral Agreement on Investment (MAI) began in 1996. The idea again was to establish a code within the OECD that non-OECD countries could opt into after its conclusion. The MAI negotiations' starting point was the investment chapter in the recently concluded North American Free Trade Agreement (NAFTA), and certain hallmark BITs. But from the beginning the MAI process was different from previous negotiations. While previous multilateral negotiations had not gained much public attention, the MAI was put under extreme media spotlight. As such, the political costs of joining the agreement increased for many states.

In practice however, the biggest obstacle the MAI negotiators faced was unbridgeable differences between countries from the European Union (EU) and non-EU countries led by 
the United States on basic investment issues (the national treatment clause in particular) (Graham, 2000, pp. 30-31). At the same time, large non-OECD countries, the most vocal of which was India, criticized the OECD for attempting to broker the MAI without formal participation from the Global South. The concerns of developing states was in turn used by OECD members who themselves opposed the MAI (e.g. Canada and Australia) to bolster their own positions (Kelley, 2000, p. 495).

There was also loud societal dissent against certain substantive provisions in the treaty (Kobrin, 1998). This civil society opposition, and the heightened media awareness around the MAI negotiations are emblematic of a more profound unravelling of the governance of the post-war liberal political economy (Walter, 2001). No longer do experts carry out international commercial negotiations without public scrutiny. Instead, there is a large and diverse epistemic community of politicians, academics, NGOs, and other civil society groupings that at any time may rally in opposition to multilateral initiatives. So, even though the MAI was crafted on basic principles of investment protection that a wide range of countries had agreed to on a bilateral basis, it was put to rest in 1998.

While the reasons for why MAI failed reflect increased complexity of investment governance in general, issues related to states' legitimate right to regulate were perhaps the overarching issue that stopped the agreement. As such, MAI also became a proxy for the larger debate around neoliberalism as the fundament of globalization:

"The failure of the MAI is less a case against true multilateralism in investment relations as such, but an illustration of the problems relating to the fine-tuning of investment protection in light of competing and legitimate public interests" (Schill, 2009, p. 58).

Although a short-lived discussion around the conditions for foreign investments resurfaced before the WTO's fourth ministerial meeting in Doha in 2001 (Wallace, 2002), there has been no real push for formal multilateralism in investment governance after the MAI. Instead bilateralism has become the modus operandi in international investment protection. 


\section{The retreat to bilateralism and private arbitration}

Figure 1 illustrates developments in international investment agreements over time. ${ }^{8}$ Less than 200 BITs were signed in the two decades after the Germany-Pakistan BIT was signed in 1959, but then things changed. In the 1980s there was a slow upswing, and between 1992 and 2010 over 100 bilateral treaties were signed per year. At its peak, in 1996, states signed over 220 investment treaties.

Unlike multilateral agreements, BITs are negotiated on a case-by-case basis and provide the two signatories with reciprocal rights and obligations. The BITs signed in the 1960s and 1970s were relatively uniform as regards substantive content and scope of application. Moreover, they were usually signed between pairs of developed and developing countries, with the intention of protecting investments made from the former in the latter's jurisdiction. For politicians and negotiators from the developing countries, the perceived bargain of BITs was that they signalled a credible commitment to an international standard of protection that would return increased inwards flows of FDI from the developed world (Poulsen, 2015).

\section{(Figure 1 here)}

Although there has been a turn towards more specific language in modern BITs, the content and application across the universe of treaties is still quite uniform. Treaties first define who is to be considered an investor and what is to be considered an investment under the treaty (i.e. who have access to treaty protection). Next, the standards for protection are laid out. In most treaties this amounts to provisions on the admission of investments and substantive guarantees. The substantive provisions usually entail guarantees on areas such as: fair and equitable treatment, full protection and security, arbitrary and discriminatory measures, national treatment, most-favoured nation treatment, expropriation, and free transfer of payments. Lastly, the disputes settlement procedures are covered. Most BITs contain ex-ante consent of states to international arbitration with investors, either before an ICSID tribunal or through other arbitration venues (Dolzer \& Schreuer, 2012).

Even though states had routinely failed to agree on such standards in multilateral negotiations, the substantive protection provided by BITs was nothing new. In fact, the content of early

\footnotetext{
${ }^{8}$ These data include BITs, regional investment treaties, and trade agreements with investment chapters. The list is based on UNCTAD's treaty list at the Investment Policy Hub (http://investmentpolicyhub.unctad.org/), but expanded through merging in various other sources.
} 
BITs was similar to the type of protection that had previously been afforded to the parties of early so-called Friendship Commerce and Navigation (FCN) treaties. ${ }^{9}$ The major innovation in BITs was the inclusion of dispute settlement through investment treaty arbitration. The inclusion of ITA provisions had from the mid-1960s and onward been promoted by the then newly established ICSID (St John, forthcoming), and this clause was effectively the first supranational remedy available to investors who experienced unlawful or uncompensated acts of expropriation by their host state. Before the rise of ITA, investors had to rely on home state diplomatic espousal or the use of domestic courts in the host state.

The actual use of ITA did not take off immediately however. But the entry into force of NAFTA in 1994 was a game-changer. At the time, most BITs were signed between countries in asymmetrical power relations and with one-way flows of FDI. NAFTA was the first treaty with an ITA clause struck between countries that all had large volumes of investments in each other's jurisdictions. Within years, all NAFTA parties had found themselves on the responding end of ITA claims by investors over acts of regulation.

Figure 2 shows all known ITA cases filed per year. ${ }^{10}$ Although recourse to ITA had been included in BITs for almost three decades, only a handful of ITA cases had been filed before NAFTA entered into force. After NAFTA, the caseload in non-NAFTA countries exploded as well. Aside from the large intra-NAFTA investment flows, the strong standing judicial dispute settlement had in the US and Canada contributed to the first explosion of cases. A side effect of this upswing was the generation of a whole new body of international arbitral practice. The practical application of arbitration to solve disputes became more apparent to investors, and expansive interpretations of certain substantive provisions by the arbitrators opened up new possibilities for law firms looking to represent aggrieved investors. The current peak of the caseload was reached in 2015, when 84 ITA claims were registered.

\section{(Figure 2 here)}

The most frequent respondent country at the time of writing is Argentina, being on the receiving end in 49 cases. Most were due to measures taken by the government in the wake of

\footnotetext{
${ }^{9}$ The FCN treaties were entered into mainly by the US after its independence to establish working relationships with its European trading partners, especially Great Britain (Vandevelde, 2010, pp. 21, 25).

${ }^{10}$ The numbers diverge from UNCTAD's official statistics because they are based on the PluriCourts Investment Treaty Adjudication (PITAD) database, in which we have found more cases than UNCTAD (Behn, Berge, \& Langford, 2016).
} 
the 2001-02 economic crisis. Without getting into the legal strength of the claims, the sheer mass of cases against the Argentina generated a debate around how legitimate the use of ITA was. However, despite such early adverse reactions against ITA, most countries were committed to the investment regime as it stood towards the end of the 2000s. Around 2010, however, active dissent against the regime intensified, and several reform proposals surfaced. We discuss these developments below, but before that we address the first research question posed in the introduction: Why is there no multilateral agreement for protecting investment?

\section{Why the recurrent failures?}

So, how do we explain that although the pre-war investment regime under customary international law was multilateral, no substantive multilateral agreement on investment has been agreed upon since? And why have so many developing countries exhibited scepticism towards substantive investor protection in multilateral forums, while agreeing to the same principles bilaterally? The historical account above suggests at least three sets of inter-related explanations.

The first is an ideational explanation tracing the primacy of BITs to the end of the Cold War protectionism, and the overwhelming global acceptance of liberal economic policy as a vehicle for economic development and growth in the late 1980s (Fukuyama, 1992). Ever since the beginning of decolonisation, many developing states had in been in desperate need of investment capital to bolster growth. For many States, this need to attract capital was furthered by the credit drought following the debt crisis in the 1980s, which had also depleted public funds significantly. When multilateralism failed, policy-makers under domestic and international strain therefore saw bilateralism as a second best option to attract investment.

The second account encompasses political explanations for the failure of multilateralism. From the point of view of capital-exporting states, the asymmetric nature of bilateral negotiations with countries from the South may have increased their chances of achieving high levels of investor protection. The idea is that in bilateral negotiations the use of (asymmetric) power is more effective than in multilateral negotiations, where the weaker parties may form alliances (Simmons, 2014, pp. 16-20). And in practice, all multilateral failures discussed here were linked to the ideological North-South divide somehow. Two partly overlapping conflicts have driven this divide. First, the decolonization process and the inclusion of former colonies in the international political dialogue led to conflict over how 
protection of property was to be understood and whether multilateralism would constitute some form of prolongation of colonial rule. Second, the post-war ideological divide between liberal economies and communist economies spurred debate around the legality of expropriation and contract protection.

An interesting facet of the North-South divide in multilateral negotiations is that its nature has changed over time. While the failure of the Havana Charter and the 1967 OECD Draft Convention was clearly caused by intangible ideological divides between developed and developing countries, the failure to agree on comprehensive rules in the MAI was mainly due to irreconcilable tensions between those favouring investor protection and those who wished to uphold competing public interest. In essence, the debate around investment governance has moved away from ideology and towards more specific policy discussions.

Another political explanation can be drawn from hegemonic stability theory: the lack of hegemonic endorsement for the proposed multilateral agreements have been hinders to their completion. Although the importance of a hegemon for making an international accord is contested (Keohane, 1984), there are at least anecdotal evidence that the US' withdrawal from the ITO negotiations in 1948 and the OECD Draft Convention in 1967 represented nails in the coffins of both these efforts.

Third, multiple technical explanations have been proposed. The first relate to the global competition for capital. As discussed above, the perceived rationale behind signing BITs for most countries in the South was that the treaties, as credible commitment devices vis-à-vis investors, would attract FDI. But FDI is scarce. So, capital-importing states face a prisoner's dilemma: as a group it is optimal for them to reject a multilateral scheme that establishes common rules for international investors everywhere. But alone, it is rational for each of these states to defect from their group's anti-multilateralist stance and negotiate bilateral agreements where they can gain an advantage over other capital importing-states in attracting FDI (Guzman, 1998). Pioneering empirical work by Poulsen (2015) confirms that the expectation of increased inwards FDI has driven eagerness to sign BITs in many developing countries.

The second technical explanation relate to the complexity of negotiating in a multilateral setting. While states in bilateral negotiations only have to accommodate the interests of two parties, there is a cobweb of interests the parties need to take into account when negotiating a multilateral treaty. As such, multilateral agreements are much more complicated to negotiate 
than bilateral ones. ${ }^{11}$ An interesting parallel in this regard is the latter years' standstill on further liberalisation of trade in the WTO system - a forum that very much has to deal with high complexity of interests.

Third, there have also been differences in the amount of attention multilateral and bilateral negotiations have received. As illustrated by the MAI, a multilateral negotiation represents a clearer focal point for the epistemic community of protestors than the thousands of bilateral investment treaty negotiations that have been conducted over the years. This creates a spotlight effect that may explain why states have retreated to bilateral negotiations on investment protection. Even though BITs include the same rules that are seen as controversial in multilateral negotiations, countries face less resistance when negotiating bilaterally. ${ }^{12}$

Lastly, one technical explanation relates to the two-level nature of political games in international negotiations. In short, diplomatic effort at the international level requires parallel and simultaneous negotiations at the domestic level in order to secure continuous support for the negotiator's position (Putnam, 1988). Discord between the policy levels may hamper the conclusiveness with which negotiators can act, perhaps best illustrated by the situation President Truman encountered when trying to get congressional support for the ITO.

As our review of the actual negotiations clearly shows, each of the three accounts has explanatory power. And while it is difficult to establish a hierarchy among the explanations, the political explanations (mainly the ideological North-South divide) seems to have been the most persistent hinder to a multilateral agreement, while the technical explanations seem to explain why states instead have turned to bilateralism best.

There is however a completely different way we can view this turn towards bilateralism. Instead of focusing on the fallacies of treaty-based multilateralism, Schill (2009) and Salacuse (2010) make the case that the regime BITs backed up by enforcement through ITA actually represent a very potent and coherent form of multilateralism without a multilateral treaty. Salacuse's argument is based on regime theory (Krasner, 1982, 1983). He argues that the universe of investment treaties, by virtue of representing common principles, norms, rules and

\footnotetext{
${ }^{11}$ This logic is derived from negotiation theory. For discussions around the differences in complexity between bilateral and multilateral negotiations, see the contributions in Zartman (1995).

12 The notion of spotlight regimes was coined by Spar (1998) in the context of why multinational enterprises from human rights obedient countries export concerns for human rights to their host states. See also Blanton and Blanton (2006) for an empirical assessment of the relationship between FDI and human rights.
} 
decision-making procedures actually do represent an integrated regime. The core of the argument is that capital-exporting states, with their reasonably similar preferences for investor protection and relatively similar model or prototype BITs, have been drivers of a uniform network of BITs. ${ }^{13}$ The community of jurists, scholars and arbitrators working within the regime has over time cemented this consistency. The result is a form of 'serial multilateralism' which only differs from the more standard 'conference multilateralism' in that it is not based on a multilateral treaty. Schill's version of the argument is complementary. In highlighting the interconnectedness of the thousands of BITs that are in force, he states:

"Unlike genuinely bilateral treaties, that is, treaties that are bilateral in form and substance, BITs do not stand isolated in governing the relation between the two contracting States only; they rather develop multiple overlaps and structural interconnectedness that $[\ldots]$ create a uniform and treatyoverarching regime for international investments" (Schill, 2009, p. 15).

Schill's point is not to say that the BIT-based investment regime is equivalent to a regime based on a multilateral treaty. The argument is that there is sufficient convergence among both the underlying ideas and the actual provisions in BITs to view the web of treaties as a de facto multilateral system.

A similar argument is advanced by UNCTAD when it points to the multilateralising effect of the ownership complexity that follows from the fact that foreign owners of a company often are based in multiple national jurisdictions:

"The broad definition of investors/investments in investment treaties, combined with the extensive networks of affiliates of large MNEs and the ease of establishing legal entities in many jurisdictions, significantly extend the protective coverage of IIAs [international investment agreements]" (UNCTAD, 2016, p. 185).

This takes us to our second research question, which we discuss in the final part of the chapter: Do we need multilateral agreement on investment?

\footnotetext{
${ }^{13}$ Model or prototype BITs are countries' starting point in BIT negotiations. One or both parties to a negotiation may prepare such drafts. The use of models have proved to be efficient when developing extensive BIT networks (Brown, 2013). For an empirical analysis of how Model BITs constitute a source of bargaining power in BIT negotiations, see Berge and Stiansen (2016).
} 


\section{Recent developments and legitimacy crisis}

While the regime of BITs had relatively strong support amongst states during the 2000s, it has come under heavy criticism in the first part of the 2010s (Van Harten, 2010). Some of the dissent concern the dynamics of ITA (Waibel, Kaushal, Chung, \& Balchin, 2010). We mentioned that the first wave of claims emanating from NAFTA was mainly a function of the large volume of investments between the US, Canada and Mexico. But in Figure 3, the ten most frequently sued countries as per 2015 are listed. In addition to the NAFTA parties, there is a clear overweight of so-called transition economies on top of the list. This skewness of lawsuits, coupled with studies showing that investment tribunals regularly favour multinationals over respondent countries has been criticised (van Harten, 2012). Claims have also been made that that ITA is vulnerable to frivolous litigation (Pelc, 2016). ${ }^{14}$

\section{(Figure 3 here)}

Some of the criticism regards the BITs themselves. The effectiveness of BITs as an instrument for attracting FDI has been questioned, ${ }^{15}$ as has the treaties' effect on host countries' room to regulate (Roberts, 2013). It has been found that developing countries, and states with high levels of negotiation expertise, dominate which rules are inserted in concluded BITs (Alschner \& Skougarevskiy, 2016; Berge \& Stiansen, 2016), and that developing countries have overestimated the benefits from BITs and underestimated the costs (Poulsen, 2015).

While UNCTAD’s Investment Policy Framework for Sustainable Development States is a sign of a higher|-level reorientation in BIT-making (UNCTAD, 2015), many countries have taken direct measures in response to the criticism of BITs. Australia intends to negotiate BITs without ITA provisions in the future. South Africa has made its intention clear to cancel all

\footnotetext{
${ }^{14}$ Frivolous litigation entail bringing weak cases where the investor claimant's primary target is not to win the suit, but to freeze acts of regulation in their host states for as long as possible. The most publicised example of frivolous litigation are the two cases tobacco giant Philipp Morris brought against Australia and Paraguay over plain packaging legislation. Even though both countries eventually won their cases, the enactment of plain packaging legislation in both countries was put on hold for the years the case lasted (Ranald, 2014).

${ }^{15}$ On the one side, a wide range of studies find general support for the proposition that BITs increase FDI, See for example: Büthe and Milner (2009), Egger and Merlo (2007), Egger and Pfaffermayr (2004) and Kerner (2009). On the other side, an equally long strand of studies is sceptical of the proposed relationship between BITs and FDI. See for example: Aisbett (2009), Hallward-Driemeier (2003), Peinhardt and Allee (2012) and Tobin and RoseAckerman (2011).
} 
BITs with European countries, and both Indonesia and India are looking to renegotiate their BITs to restrict access to ITA and reduce substantive investor protection.

The critique against ITA has mostly concerned the secrecy and structure of the proceedings. ${ }^{16}$ There are concerns over the lack of an appellate mechanism and of the independence of the arbitrators, notably their tendency to favour investors over developing countries. ${ }^{17}$ The fact that the same person can act as legal counsel and expert witnesses in parallel cases, while at the same time sitting as arbitrator in a parallel but separate case is often highlighted as problematic. So is the fact that almost 70 percent of all arbitrators come from North America and Europe (ICSID, 2016). As a direct result of mistrust in ITA, Bolivia, Ecuador and Venezuela, all denounced the ICSID convention during the 2000s.

\section{Do we need a multilateral agreement?}

While history certainly shows that achieving multilateral concord on investment is difficult, the more relevant question is perhaps: Is a multilateral agreement on investment needed? There are still voices that favour formal multilateralism (Lin, 2016; Åslund, 2013), but an interesting perspective in the context of the current move towards regionalisation of investment governance has also been forwarded under the TPP and TTIP is forwarded by:

"[If] the shortcomings of the current investment regime can be better dealt with in the context of regional negotiations; these should, however, be accompanied by a political dialogue at the global level" (Berger, 2013, pp. 3-4).

The global forum suggested is the G20, and the argument is that coordinated regionalism may allow for both regional adaptations of regulations and high-level discussions around overarching issues such as public health regulation and transparency.

However, it seems like the TPP and TTIP negotiators are feeling the consequences of the legitimacy debate and the extreme media spotlight as well. Even though there have been lively domestic discussions around lowering of standards, it is undoubtedly the agreements' ITA chapters that have received the most vociferous attention. While the new Trump

\footnotetext{
${ }^{16}$ See Dezalay and Garth (1998) for a review of how international commercial arbitration rose to prominence, and what role individual arbitrators have played, and play, in the development of this transnational legal order.

${ }^{17}$ Arbitrators have for example been found to side with foreign investors more often than developing countries in the interpretation of contestable terms in BITs (van Harten, 2012), but Behn et al. (2016) suggest that ITA is not skewed in favour of investors. If skewed at all, it is rather in favour of rich respondent countries.
} 
administration in the US seems to withdraw the country from all multilateral economic negotiations, the EU has faced their own uphill battle to conclude the TTIP. And in response to criticism from within the EU, the EU Commission has proposed to address the lack of an appellate mechanism in ITA and the concerns over arbitrator independence with a standing investment court (Titi, 2016).

How the investment regime will adapt to the legitimacy crisis and the new US policy on economic diplomacy is difficult to predict. What is safe to say is that the regime is at a crossroads. While the substantive principles and practices of international investment governance have been discussed in many forums at different points in time, the current discussion is founded in a more thorough understanding of how ITA works and what the economic effects of treaties are. It remains to be seen whether the systemic expertise is put to use by policy-makers. 


\section{Literature}

Aisbett, E. (2009). Bilateral Investment Treaties and Foreign Direct Investment: Correlation versus Causation. In K. P. Sauvant \& L. Sachs (Eds.), The Effect of Treaties on Foreign Direct Investment. New York: Oxford University Press.

Alschner, W., \& Skougarevskiy, D. (2016). Mapping the Universe of International Investment Agreements. Journal of International Economic Law, 1-28.

Behn, D. F., Berge, T. L., \& Langford, M. (2016). Poor States or Poor Governance. Explaining the Outcomes of Investment Treaty Abitration. Working paper available at SSRN.

Berge, T. L., \& Stiansen, $\varnothing$. (2016). Negotiating BITs with Models: The Power of Expertise. Working paper available at SSRN.

Berger, A. (2013). Do We Really Need a Multilateral Investment Agreement? Briefing Paper 9/2013, German Development Institute.

Blanton, S. L., \& Blanton, R. G. (2006). Human Rights and Foreign Direct Investment A Two-Stage Analysis. Business \& Society, 45(4), 464-485.

Brown, C. (2013). Introduction: The Development and Importance of the Model Bllateral Investment Treaty. In C. Brown (Ed.), Commentaries on Selected Model Investment Treaties. Oxford: Oxford University Press

Burt, E. M. (1997). Developing Countries and the Framework for Negotiations on Foreign Direct Investment in the World Trade Organization. Am. UJ Int'I L. \& Pol'y, 12, 1015.

Büthe, T., \& Milner, H. V. (2009). Bilateral Investment Treaties and Foreign Direct Investment: A Political Analysis. In K. P. Sauvant \& L. Sachs (Eds.), The Effects of Treaties on Foreign Direct Investment (pp. 171-224). New York: Oxford University Press.

Dattu, R. (2000). A Journey from Havana to Paris: The Fifty-Year Quest for the Elusive Multilateral Agreement on Investment. Fordham International Law Journal, 24, 275.

Dezalay, Y., \& Garth, B. G. (1998). Dealing in Virtue: International Commercial Arbitration and the Construction of a Transnational Legal Order. Chicago: University of Chicago Press.

Dolzer, R., \& Schreuer, C. (2012). Principles of international investment law. Oxford: Oxford University Press.

Egger, P., \& Merlo, V. (2007). The Impact of Bilateral Investment Treaties on FDI Dynamics. The World Economy, 30(10), 1536-1549.

Egger, P., \& Pfaffermayr, M. (2004). The Impact of Bilateral Investment Treaties on Foreign Direct Investment. Journal of Comparative Economics, 32(4), 788-804.

Fukuyama, F. (1992). The End of History and the Last Man. New York: Free Press.

Graham, E. M. (2000). Fighting the Wrong Enemy: Antiglobal Activists and Multinational Enterprises. Washington, DC: Peterson Institute for International Economics.

Guzman, A. T. (1998). Why LDCs Sign Treaties That Hurt Them: Explaining the Popularity of Bilateral Investment Treaties. Virginia Journal of International Law, 38, 639. 
Hallward-Driemeier, M. (2003). Do Bilateral Investment Treaties Attract Foreign Direct Investment? Only a Bit and They Could Bite. Development Group Policy Research Working Paper. World Bank. Washington DC.

Hopkins, A. G. (1980). Property Rights and Empire Building: Britain's Annexation of Lagos, 1861. The Journal of Economic History, 40(04), 777-798.

Hveem, H. (2006). Explaining the Regional Phenomenon in an Era of Globalization. In R. Stubbs \& G. R. D. Underhill (Eds.), Political Economy and the Changing Global Order. Oxford: Oxford University Press.

ICSID. (2016). The ICSID Caseload - Statistics. Washington, DC: ICSID.

Kelley, G. (2000). Multilateral Investment Treaties: A Balanced Approach to Multinational Corporations. Columbia Journal of Transnational Law, 39, 483.

Keohane, R. O. (1984). After Hegemony. Cooperation and Discord in the World Economy. Princeton: Princeton University Press.

Kerner, A. (2009). Why Should I Believe You? The Costs and Cnsequences of Bilateral Investment Treaties. International Studies Quarterly, 53(1), 73-102.

Kobrin, S. J. (1980). Foreign Enterprise and Dorced Divestment in LDCs. International Organization, 34(1), 65-88.

Kobrin, S. J. (1998). The MAI and the Clash of Globalizations. Foreign Policy(Autumn), 97-109.

Kolk, A., \& Van Tulder, R. (2005). Setting new global rules? TNCs and codes of conduct. Transnational Corporations, 14(3), 1-27.

Krasner, S. D. (1982). Regimes and the Limits of Realism: Regimes as Autonomous Variables. International Organization, 36(02), 497-510.

Krasner, S. D. (1983). International Regimes. Ithaca: Cornell University Press.

Kurtz, J. (2002). A general investment agreement in the WTO? Lessons from Chapter 11 of NAFTA and the OECD multilateral agreement on investment. University of Pennsylvania Journal of International Economic Law, 23(4).

Lin, J. Y. (2016). China's G20 Agenda: Call for a Multilateral Investment Framework for Development G20 Hangzhou Summit 2016. Proposals for Trade, Investment, and Sustainable Development Outcomes (pp. 55-60). Geneva: ICTSD.

OECD. (2008). OECD Benchmark Definition of Foreign Investment. 4th edition. Paris: OECD Publishing.

Peinhardt, C., \& Allee, T. (2012). Failure to Deliver: The Investment Effects of US Preferential Economic Agreements. The World Economy, 35(6), 757-783.

Pelc, K. (2016). Does the International Investment Regime Induce Frivolous Litigation? Working paper available at SSRN.

Poulsen, L. N. S. (2015). Bounded Rationality and Economic Diplomacy: The Politics of Investment Treaties in Developing Countries. Cambridge: Cambridge University Press.

Putnam, R. D. (1988). Diplomacy and domestic politics: the logic of two-level games. International organization, 42(3), 427-460. 
Ranald, P. (2014). Expropriating Public Health Policy: Tobacco Companies' Use of International Tribunals to Sue Governments over Public Health Regulation. The Journal of Australian Political Economy(73), 76.

Roberts, A. (2013). Clash of Paradigms: Actors and Analogies Shaping the Investment Treaty System. American journal of international law, 107(1), 45-94.

Salacuse, J. W. (2010). The Emerging Global Regime for Investment. Harvard International Law Journal, 51(2), 427-473.

Schill, S. W. (2009). The Multilateralization of International Investment Law. New York: Cambridge University Press.

Schreuer, C. H. (2009). The ICSID Convention: A Commentary. Cambridge: Cambridge University Press.

Schwarzenberger, G. (1969). Foreign Investments and International Law. London: Sweet \& Maxwell.

Shea, D. R. (1955). The Calvo Clause: A Problem of Inter-American and International Law and Diplomacy. Minneapolis: University of Minnesota Press

Shenkin, T. S. (1993). Trade-Related Investment Measures in Bilateral Investment Treaties and the GATT: Moving Toward a Multilateral Investment Treaty. University of Pittsbrugh Law Review, 55, 541-606.

Simmons, B. A. (2014). Bargaining over BITs, Arbitrating Awards: The Regime for Protection and Promotion of International Investment. World Politics, 66(01), 12-46.

Sornarajah, M. (2010). The International Law on Foreign Investment. New York: Cambridge University Press.

Spar, D. L. (1998). The Spotlight and the Bottom Line: How Multinationals Export Human Rights. Foreign Affairs(March/April).

Spero, J. E., \& Hart, J. A. (2003). The Politics of International Economic Relations (6th ed.). Boston: Cengage Learning.

St John, T. (2016). Failed but not Forgotten: Explaining the Influence of Unsuccesful Multilateral Negotiations. Paper presentated at the 2016 International Studies Association (ISA) Annual Convention.

St John, T. (forthcoming). The Rise of Investor-State Arbitration: Politics, Law, and Unexpected Consequences. Oxford: Oxford University Press.

Titi, C. (2016). The European Union's Proposal for an International Investment Court: Significance, Innovations and Challenges Ahead. Transnational Dispute Management, 25.

Tobin, J. L., \& Rose-Ackerman, S. (2011). When BITs Have Some Bite: The Political-Economic Environment for Bilateral Investment Treaties. The Review of International Organizations, 6(1), 1-32.

Tschofen, F. (1992). Multilateral Approaches to the Treatment of Foreign Investment. ICSID Review, $7(2), 384-427$.

UNCTAD. (2015). Investment Policy Framework for Sustainable Development. New York/Geneva: UNCTAD. 
UNCTAD. (2016). World Investment Report 2016. Investor Nationality: Policy Challenges. New York/Geneva: UNCTAD.

Van Harten, G. (2010). Five Justifications for Investment Treaties: A Critical Discussion. Trade, Law \& Development, 2, 19.

van Harten, G. (2012). Arbitrator Behaviour in Asymmetrical Adjudication: An Empirical Study of Investment Treaty Arbitration. Osgoode Hall Law Journal, 50, 211-268.

Vandevelde, K. J. (2010). Bilateral ilnvestment Treaties: History, Policy, and Interpretation. New York: Oxford University Press.

Waibel, M., Kaushal, A., Chung, K.-H. L., \& Balchin, C. (2010). The Backlash Against Investment Arbitration: Perceptions and Reality. The Netherlands: Kluwer Law International.

Wallace, C. D. (2002). The Legal Environment for a Multilateral Framework on Investment and the Potential Role of the WTO. Journal of World Investment, 3, 289-326.

Walter, A. (2001). NGOs, business, and international investment: the Multilateral Agreement on Investment, Seattle, and beyond. Global Governance, 7, 51.

Zartman, I. W. (1995). International Multilateral Negotiation: Approaches to the Management of Complexity. San Francisco: Jossey-Bass.

Åslund, A. (2013). The World Needs a Multilateral Investment Agreement (Vol. January). Washington, DC: Peterson Institute for International Economics. 